\title{
Youtube As Innovation in Teaching Words Equivalent of Bahasa Indonesia
}

\section{Kadek Wirahyuni}

Language and Literature of Indonesia Education Department, Undiksha

\section{Abstract}

Language establishment and development is one of the subjects in Bahasa Indonesia Department which more focus on the application or use of Bahasa Indonesia in the society and the development of Bahasa Indonesia in accordance with the progress of the times. One of them is to allow foreign words into the word equivalent in Bahasa Indonesia. There are still few people who know or even use the words equivalent in daily life. In fact, the words equivalent of Bahasa Indonesia are no less cool than the foreign language. In today's technological age, audiovisual information gets more attention in society, especially for today's teenagers. They seem addicted in watching videos rather than reading books. All of information and lesson which are gained from

Corresponding Author: Kadek Wirahyuni wirahyuni27@gmail.com

Received: 23 January 2019 Accepted: 26 February 2019 Published: 17 March 2019

Publishing services provided by Knowledge E

(c) Kadek Wirahyuni. This article is distributed under the terms of the Creative Commons

Attribution License, which permits unrestricted use and redistribution provided that the original author and source are credited.

Selection and Peer-review under the responsibility of the International Seminar on Language, Education, and Culture Conference Committee. watching video is more quickly absorbed than giving lecture or displaying material in the slides. Therefore, a short video of word equivalent is made and it is broadcasted on Youtube. This kind of innovation also takes advantage from media such as gadget or portable computers in learning. Teaching words equivalent through Youtube media are done into three steps, namely: introduction of words equivalent, creating video of words equivalent, and implicating video of words equivalent on Youtube. This research is a descriptive qualitative research. Around $96 \%$ of college students deliver positive responses on the video which is made and displayed properly as learning material about word equivalent. All college students state that Youtube can improve their learning motivation. Youtube can also add their creativity to create an interesting video. Teachers can take advantage of short video about word equivalent on Youtube and apply it into learning material, such as making or organizing sentences, writing paragraphs, writing poems, delivering speech, and so on. The more often word equivalent are applied or used by students, the vocabulary of Bahasa Indonesia also automatically increase. Innovation of teaching word equivalent of Bahasa Indonesia into a short video on Youtube is a creative learning which is adapted on the current development.

Keywords: Youtube, learning innovation, words equivalent of Bahasa Indonesia

\section{Introduction}

A lot of things can determine learning success. Several subsystem that determine learning success are media/learning tools, technology, and teacher itself (Paulina, 2005). One 
nowadays is Youtube. Youtube is a page which facilitates the user for sharing their own video. Youtube is widely used among teenager, even children can use this feature. There are several advantages of using Youtube in learning as follows. It makes students to have online discussion through Youtube interestingly; it is used to upload the content of video and becomes learning material; it is used to create effective and efficient presentation on Youtube video channel; it helps developing the ability of students to give comment on the video that is watched and it develops the creativity of students for creating video that is uploaded on Youtube (Hasanah, 2016). Nowadays, Youtube is one of the most popular video sharing service on internet (Snelson, 2011). The inclusion of Youtube as an alternative learning media can enhance the skills of collaboration and technology integration into education program. In addition, Youtube can stimulate active learning and provide additional knowledge beyond the expected ability (Agazio \& Buckley, in Lestari, 2017). Basically, Youtube can pampers its subscribers by providing videos of 'anything' that want to be watched. The available videos are also various and very interesting. Youtube becomes one of the fastest growing websites. Currently, besides as entertainment, the videos on Youtube also have connected with education. The educational videos contain various subjects. It greatly helps the students to understand material easily from watched video.

\section{Method of Research}

This research was a descriptive qualitative research. This research was based on the activities of Establishment and Development Bahasa Indonesia Course in sixth semester with total of 74 people, Language and Literature Bahasa Indonesia Education Department, University of Ganesha Education. The research went on for fourteen weeks during even semester of 2017/2018. At the end of semester, college students filled out questionnaire about opinion and responded about the use of Youtube as a learning media.

\section{Result of Research}

The innovation of learning is really needed to enhance the learning interest of students, it makes students easy to understand material and build curiosity of students toward explained material. Therefore, learning innovation should be on the right and appropriate target. There are several innovations which are conducted by teacher. One of them that I use is Youtube. Youtube is used in learning word equivalent. The existence of Bahasa Indonesia can be recalculated by using media that is close and often used by 
the society. Teaching word equivalent through Youtube media is done by following 3 steps as follows.

1. Introducing word equivalent of English into Bahasa Indonesia.

There are several words equivalent which are introduced to college students as follows.

There are several words along with their word equivalent which are mentioned above before. After that, lecturer decided several groups. Each group got five words equivalent. They were sorted from number one to five and so on. Then, each group took note of word equivalent which will be used in creating video. The limitation of time to make a video was two weeks.

(2) Creating video of words equivalent

Here is the Youtube address which consists of learning video about word equivalent.

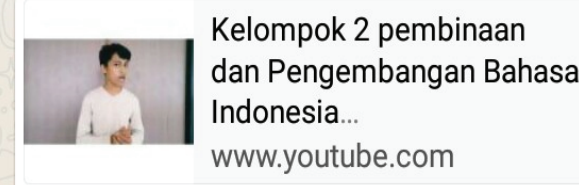

https://m.youtube.com/watch? $\mathrm{v}=\mathrm{KaVdrUcBg} 2 \mathrm{~A}$

https://youtu.be/qOB9BZlgJV4

https://www.youtube.com/watch? $v=40$ CfhS3PHIg\&feature=youtu.be

https://youtu.be/g_jd3bZAaPQ $\quad 14.09$
Kelompok Devi :

https://m.youtube.com/watch?

v=IgOiOOxPcoY\&feature=youtu.be

Kelompok Novia :

http://www.youtube.com/watch?v=r-6DAJjbjA

Kelompok Agus :

https://www.youtube.com/watch?

$v=1 \mathrm{MHAmP6ZEHk}$

Kelompok Sugiarta :

https://youtu.be/NQfRFoG-DW4

Kelompok Diah Ayu :

https://youtu.be/ODbwg_KP2m8

Figure 1: Youtube address of learning word equivalent.

(3) Exchanging information of words equivalent from watched video

During learning process, after creating and watching video about words equivalent, college students were asked to retell words equivalent in watched video on Youtube. After that, another student gave comment on it. Despite of commenting, each group was also given questions about others words equivalent. If the group could answer, the group would be given point as a form of appreciation. Learning words equivalent along with this kind of media was really interesting. Besides college students were asked to be creative in using media, they could also remember 
TABLE 1: Several examples of allowed word equivalent.

\begin{tabular}{|c|c|c|}
\hline No. & Words & Words Equivalent \\
\hline 1. & Netizen & Warganet \\
\hline 2. & Copy paste & Salin rekat \\
\hline 3. & Lip-sync & Suai bibir \\
\hline 4. & Gadget & Gawai \\
\hline 5. & Preview & Pralayang \\
\hline 6. & Power Bank & Bank daya \\
\hline 7. & Selfie & Swafoto \\
\hline 8. & Timeline & Linimasa \\
\hline 9. & Lobby & Selasar \\
\hline 10. & Bypass & Jalan Bentar \\
\hline 11. & Manner & Jatmika \\
\hline 12. & Really sleepy & Meralik \\
\hline 13. & Door prize & Hadiah lawing \\
\hline 14. & Flash disk & Diska Lepas \\
\hline 15. & Appetizer & Penyelera \\
\hline 16. & Brand & Jenama \\
\hline 17. & Deadline & Tenggang/ tenggat \\
\hline 18. & Indolent & Kelesa \\
\hline 19. & Subtitle & Sulih teks \\
\hline 20. & Mouse & Tetikus \\
\hline 21. & Website & Laman \\
\hline 22. & Email & Pos-el/ surel \\
\hline 23. & Contact person & Narahubung \\
\hline 24. & E-KTP & KTP-el \\
\hline 25. & Hand body lotion & Calir badan \\
\hline 26. & Mie instant & Mi dadak \\
\hline 27. & Hyperlink & Pranala \\
\hline 28. & Power point & Salindia \\
\hline 29. & Out bond & Mancakrida \\
\hline 30. & Next two days & Tulat \\
\hline 31. & Next three days & Tubin \\
\hline 32. & Caption & Takarir \\
\hline 33. & Hashtag & Tagar \\
\hline 34. & Study tour & Tur studi \\
\hline 35. & Margin & Pias \\
\hline 36. & Passion & Renjana \\
\hline 37. & Ballyhoo & Kain Rentang \\
\hline 38. & Laundry & Penatu \\
\hline 39. & Laptop & Komputer jinjing \\
\hline 40. & Refund & Restitusi \\
\hline
\end{tabular}

words equivalent by opening the available page. The video which is made by them 


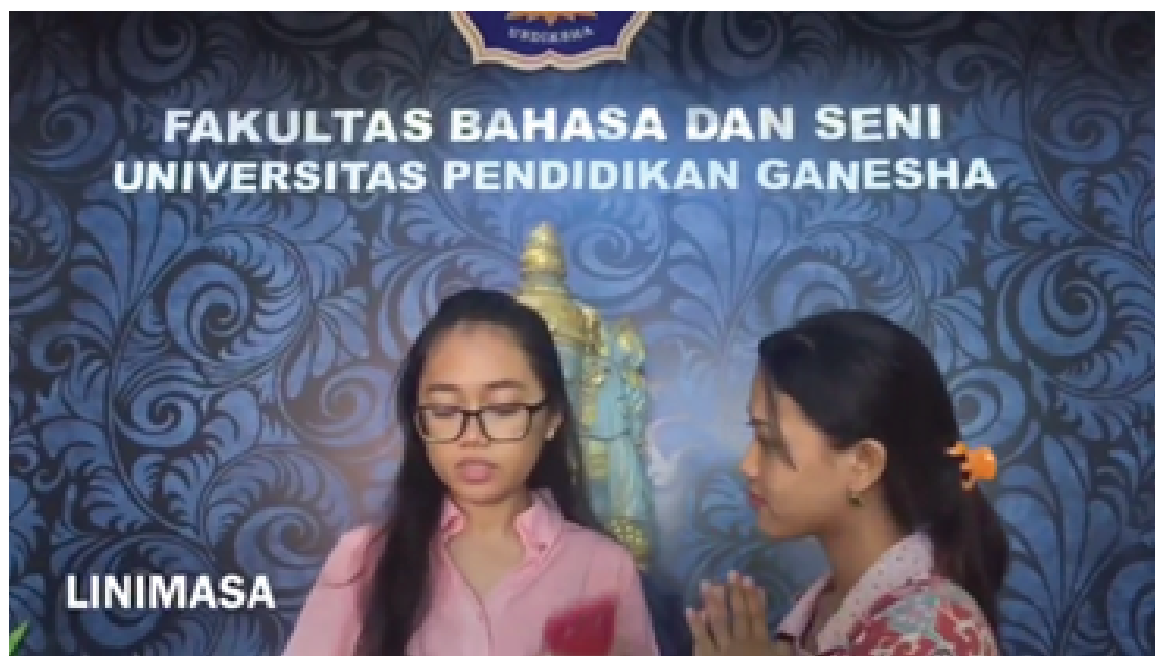

Figure 2: Scene of learning video about word equivalent on Youtube.
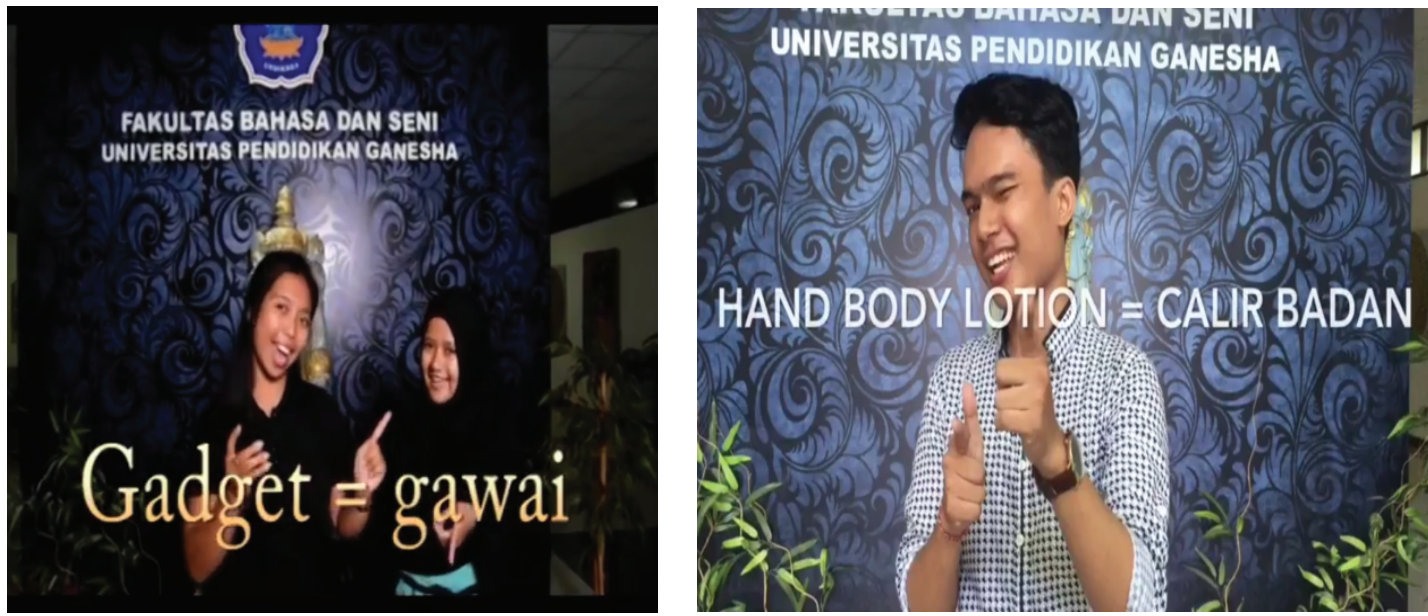

Figure 3: Scene of learning video about word equivalent on Youtube.

can also be shared in several social media, so it doesn't only give benefit for our self but also for all society.

College students' perception about the use of Youtube as learning media of words equivalent used Liker scale with 15 questions including answer 'disagree' until 'very agree'. The first part consisted of 14 questions about college students' perception toward the creation and use of Youtube in the class. Around 53 (72\%) college students stated 'agree' and 21 (28\%) college students stated 'very agree' that the use of Youtube could increase their learning motivation toward words equivalent. Not only that, around $90 \%$ college students stated that learning words equivalent through Youtube could help students to remember and comprehended given words equivalent; the rest of $10 \%$ stated that Youtube could also spend a lot of their time. The second part consisted of five questions about creating video of the word equivalent. A total of $96 \%$ of college students delivered positive responses on the 
videos that were made and displayed. The videos were used as learning media of word equivalent and they were very interesting. All college students stated that Youtube could improve their learning motivation. Youtube can also add their creativity in creating an interesting video. It is because, uploaded videos on Youtube are not only watched by their groups, but also by big community.

\section{Conclusion}

Innovation of learning word equivalent in Bahasa Indonesia through Youtube was very interesting. College students were more enthusiastic in learning and they could also use the media such as portable computers or gadget to upload and watch videos. A lot of quota was needed to watch video on Youtube as the lack of it. If you had free Wi-Fi at your place, you could watch it smoothly. If there was no free Wi-Fi provided, you should prepare to spend a large enough quota to watch videos about learning word equivalent. Another way to watch it was that the teachers could download video about the words equivalent then displayed them on screen using LCD and portable computers.

\section{References}

[1] Fauzie, Mohammad. 2012. Keberkesanan Penggunaan Youtube dalam Pengajaran dan Pembelajaran. https://www.scribd.com/doc/79176528/KeberkesananPenggunaan-Youtube-Dalam-Pengajaran-Dan-Pembelajaran. Diunduh pada tanggal 11 Januari 2018.

[2] Hasanah, Nove. 2016. Manfaat Youtube untuk Pembelajaran Guru. http://novehasanah.blogspot.com/2016/10/manfaat-youtube-untuk-pembelajaranguru.html.Diunduh pada tanggal 7 Juli 2017.

[3] Iga Luhsasi, Dwi \& Sadjiarto, Arief. 2017. "Youtube: Trobosan Media Pembelajaran Ekonomi Bagi Mahasiswa", Jurnal Ekonomi Pendidikan dan Kewirausahaan (Vol. 5 Nomor 2). HIm 219 - 229.

[4] Lestari, Renda. 2017. Penggunaan Youtube sebagai Media Pembelajaran Bahasa Inggris. https://publikasiilmiah.ums.ac.id/bitstream/handle/11617/9566/68.pdf?sequence=1.Di pada tanggal 18 Maret 2018.

[5] Paulina, Pannen. 2005. Pendidikan sebagai Sistem. Jakarta: Universitas Terbuka.

[6] Snelson, C. 2011. Youtube Across the Disciplines: A Review of Literature. MERLOT Journal of Online Learning and Teaching Vol. 7, No.1, March 2011. 